\title{
Relationship Between Patient's Perception of Service Quality and Use of Outpatient Services
}

\section{Lia Idealistiana* and Wuri Ciptaningsih}

Sekolah Tinggi IImu Kesehatan Abdi Nusantara

\section{ORCID}

Lia Idealistiana: https://orcid.org/0000-0001-9078-3616

Abstract. Outpatient services need to be prioritized because they are often the start of a patient's use of health services and can improve the image of the hospital, so that it continues to be the hospital of choice for patients and improves its profits. This descriptive research used a cross-sectional approach. Univariate analyses and bivariate analyses (the Chi-square test) were used. According to the results, there was a significant relationship between the perception of empathy ( $p=0.017$ ), responsiveness $(p=0.015)$, and assurance $(p=0.006)$ with service utilization. There was no significant

Corresponding Author: Lia Idealistiana; email:

liaidealistiana@gmail.com

Published: 7 February 2022

Publishing services provided by Knowledge E

(c) Lia Idealistiana and Wuri Ciptaningsih. This article is distributed under the terms of the Creative Commons

Aftribution License, which permits unrestricted use and redistribution provided that the original author and source are credited.

Selection and Peer-review under the responsibility of the IVCN Conference Committee.
G OPEN ACCESS relationship between tangible perception $(p=0.099)$, or reliability $(p=0.062)$ by using outpatient services. Although a relationship was found in some but not all of the perceptions of patients related to the dimensions of service quality, the quality of service should remain a priority, and it is hoped that future researchers will investigate other influencing factors.

Keywords: perception, service quality dimensions, service utilization

\section{Introduction}

According to Law number 44 of 2009, a hospital is a health service institution that provides complete individual health services that provide inpatient, outpatient and emergency services. The hospital does not only work for curative activities, but is a place to improve the health status of individuals, so that the quality of health and human life in Indonesia also increases. In facing the era of decentralization and economic globalization, hospitals face various challenges and changes. Changes in disease epidemiology, changes in demographic structure, developments in science and technology, socioeconomic changes in society increasingly demand higher quality health services [1].

Based on data from the Ministry of Health [2] in Indonesia, there were 2,813 hospitals until the end of 2018. The number consisted of 2,269 General Hospitals and 544 Special Hospitals. As is known, the private sector has 1,787 hospitals or $63.5 \%$ of the total in homeland. The trend of increasing the number of hospitals which is increasing year by year indicates that hospitals must be able to compete. Therefore, hospitals that 
have been established and operating today must prepare themselves to foster their organizations to be able to create quality hospital health services for their customers.

Port Medical Center Hospital is a subsidiary of IPC Pelindo II which was established for 16 years, located in a strategic location in front of the port entrance on Jalan Enggano No. 10 Tanjung Priuk. In its development, many new hospitals have become competing hospitals, including Puri Medika Hospital, Sukmul Hospital, Mulya Sari Hospital, Koja Hospital and the surrounding hospitals. RS Port medical Center has various types of health services that can be featured to maintain patient loyalty. One of the health services in the hospital is outpatient services. Outpatient services are the main concern of hospital management because the number of outpatients is more than other treatments. Outpatient services are health services that really need to be considered because they are the beginning of patients in utilizing other health services. In this case, outpatient services are good can improve the image of the hospital. Therefore, to increase the profit center of the hospital, the outpatient management must get special attention.

Based on medical record data at the Port Medical Center Hospital, the realization of outpatient visits until 2018 was 57690 people from 36161 people budgeted or realized $59.54 \%$ above the budget. When compared with the realization in 2017 there was an increase of $7.25 \%$ from 53791 people to 57690 people. However, the realization of outpatient visits in 2019 decreased by around 17.57\% compared to 2018 from 57690 people to 47551 people.

When viewed from outpatient visits for the past three years, it shows a decrease in the number of old patient visits in outpatient units. The decline in the number of old patient visits, especially from 2017 to 2019 reached 5295 visits. Likewise, the growth of new patients decreased by $17.4 \%$. Thus, in order to remain the hospital of choice for patients, the Port Medical Center Hospital must continue to improve the quality of its services. As according to McDougall and Levesque [3], in their book "customer satisfaction" suggests, consumer satisfaction depends on the quality of service or all services received. by consumers. Likewise Parasuraman [4], suggests that service quality is a measure of a comprehensive assessment of the level of a good service.

\section{Methods}

\subsection{Design}

This research is a quantitative research with a cross sectional research design, where the sampling of the object is only done once and at the same time. 


\subsection{Sample}

The number of samples in this study was determined based on sample calculations carried out using the Slovin formula for 103 respondents with inclusion criteria: Outpatients who have received services from the Port Medical Center Hospital, Patients who have used health services previously at Port Medical Center Hospital outpatients, and can communicate well, if not for example a child patient, the substitute is the introduction (parents or relatives).

\subsection{Procedure}

Data was collected through direct interviews with respondents using questionnaires. The sample size is 103 outpatient respondents except employees and their families. The way that the researchers did in getting respondents was when they were going to conduct interviews, the researchers first asked the visiting patients whether they were willing to be interviewed or not. Then if the patient does not meet the criteria as respondents who can be interviewed, the researcher will not conduct interviews and will look for other patients who meet the criteria that have been previously set. The results are displayed in the form of a table accompanied by an explanation

\subsection{Questionnaire for Data Collection}

The questionnaire has gone through the results of the validity test and reliability test with the results: on the Tangibel variable there are 8 question items that have passed the validity test with a correlation $r$ value $>/ 0.25$, there are 2 question items that are invalid and removed with a correlation value of 0.143 and 0.123 , namely the hospital is in a strategic location and has public telephone/wifi facilities. In the Assurance variable of the 6 question items, there is 1 item that is not valid with a correlation $r$ value of 0.220 , namely the doctor's question serves with a convincing attitude and the patient feels safe. The variables of Empathy, Reliability and Responsiveness all question items have all validity. The reliability test was carried out with the Cronbach alpha test with an alpha value of 0.928 which means it has perfect reliability (if alpha $>0.90$ then perfect reliability). 
TABLE 1: Frequency Distribution of Patient Perceptions About Dimensions of Service Quality and Service Utilization in Outpatient Hospital Port Medical Center

\begin{tabular}{|c|c|c|c|}
\hline \multirow{2}{*}{\multicolumn{2}{|c|}{$\begin{array}{l}\text { Perceptions About Dimensions of Service } \\
\text { Quality and Service Utilization }\end{array}$}} & \multicolumn{2}{|c|}{ Frequency } \\
\hline & & $\mathrm{N}$ & $\%$ \\
\hline \multicolumn{4}{|c|}{ Perception of Physical Evidence (Tangibel) } \\
\hline Good & & 47 & $45,6 \%$ \\
\hline Less & & 56 & $54,4 \%$ \\
\hline \multicolumn{4}{|c|}{ Perception of Empathy (Attention) } \\
\hline Good & & 64 & $62,1 \%$ \\
\hline Less & & 39 & $37,9 \%$ \\
\hline \multicolumn{4}{|c|}{ Perception of Reliability (Reliability) } \\
\hline Good & & 40 & $38,8 \%$ \\
\hline Less & & 63 & $61,2 \%$ \\
\hline $\begin{array}{l}\text { Perception of } \\
\text { (Responsiveness) }\end{array}$ & Responsiveness & & \\
\hline Good & & 44 & $42,7 \%$ \\
\hline Less & & 59 & $57,3 \%$ \\
\hline \multicolumn{4}{|c|}{ Perception of Assurance (Assurance) } \\
\hline Good & & 71 & $68,9 \%$ \\
\hline Less & & 32 & $31,1 \%$ \\
\hline \multicolumn{4}{|l|}{ Service Utilization } \\
\hline Good & & 41 & $39,8 \%$ \\
\hline Less & & 62 & $60,2 \%$ \\
\hline Total & & 103 & $100 \%$ \\
\hline
\end{tabular}

\subsection{Data Analysis}

The data were analyzed by SPSS/WIN version 23. Descriptive statistics were used to explain the demographic information of the respondents, as well as other research variables. chi-square test was used to find the relationship between variables. The $p$ value $<.05$ was considered significant.

\section{Results}

\section{Discussion}

The quality of health services in hospitals can be seen from customer satisfaction in receiving services provided by health organizations. Customer satisfaction is seen as a determining element in the assessment of the good and bad of a hospital. According to [5], there are three components that influence the satisfaction of a hospital, namely 
TABLE 2: Analysis of the Relationship between Patient Perception of Tangibles (Physical Evidence) and Service Utilization

Patient
Perception
of Tangibles
(Physical
Evidence)
Good
Less
Total

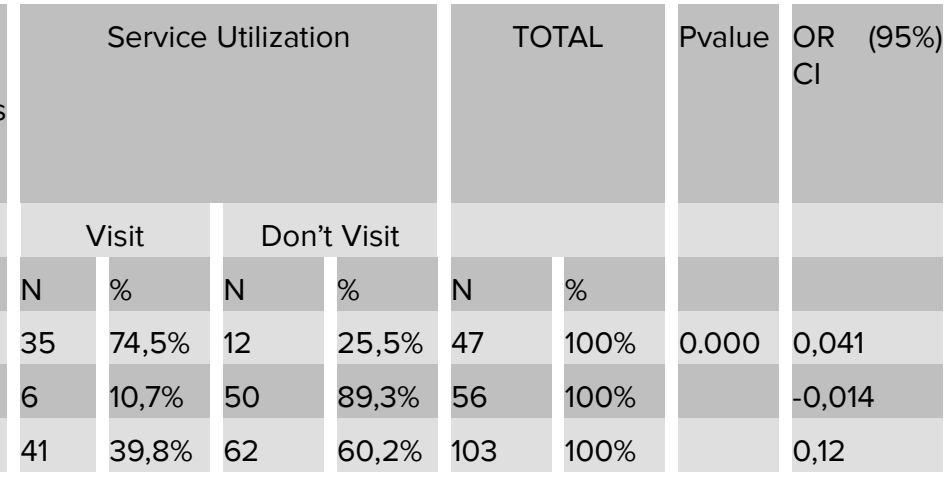

TABLE 3: Analysis of the Relationship between Perception of Empathy (Attention) and Service Utilization

\begin{tabular}{|c|c|c|c|c|c|c|c|c|}
\hline \multirow{3}{*}{$\begin{array}{l}\text { Perception } \\
\text { of } \\
\text { Empathy } \\
\text { (Attention) }\end{array}$} & \multicolumn{4}{|c|}{ Service Utilization } & \multicolumn{2}{|c|}{ TOTAL } & \multirow[t]{3}{*}{ Pvalue } & \multirow[t]{3}{*}{ OR ( $95 \% \mathrm{Cl})$} \\
\hline & \multicolumn{2}{|c|}{ Visit } & \multicolumn{2}{|c|}{ Don't Visit } & & & & \\
\hline & $\mathrm{N}$ & $\%$ & $\mathrm{~N}$ & $\%$ & $\mathrm{~N}$ & $\%$ & & \\
\hline Good & 34 & $53,1 \%$ & 30 & $46,9 \%$ & 64 & $100 \%$ & 0,001 & 0,193 \\
\hline Less & 7 & $17,9 \%$ & 32 & $82,1 \%$ & 39 & $100 \%$ & & $-0,074$ \\
\hline Total & 41 & $39,8 \%$ & 62 & $60,2 \%$ & 103 & $100 \%$ & & 0,501 \\
\hline
\end{tabular}

TABLE 4: Analysis of the Relationship between Patient Perception of Responsiveness (Responsiveness) and Service Utilization

Patient Perception
of Responsiveness
(Responsiveness)
Good
Less
Total

\begin{tabular}{|c|c|c|c|c|c|c|c|}
\hline \multicolumn{4}{|c|}{ Service Utilization } & \multicolumn{2}{|c|}{ TOTAL } & \multirow[t]{2}{*}{ Pvalue } & \multirow{2}{*}{$\begin{array}{l}\text { OR ( } 95 \% \\
\mathrm{Cl})\end{array}$} \\
\hline & Visit & & n't Visit & & & & \\
\hline N & $\%$ & $\mathrm{~N}$ & $\%$ & $\mathrm{~N}$ & $\%$ & & \\
\hline 38 & $86,4 \%$ & 6 & $13,6 \%$ & 44 & $100 \%$ & 0,000 & 0,008 \\
\hline 3 & $5,1 \%$ & 56 & $94,9 \%$ & 59 & $100 \%$ & & $-0,002$ \\
\hline 41 & $39,8 \%$ & 62 & $60,2 \%$ & 103 & $100 \%$ & & 0,036 \\
\hline
\end{tabular}

TABLE 5: Analysis of the Relationship between Patient Perception of Assurance (Assurance) and Service Utilization

\begin{tabular}{|c|c|c|c|c|c|c|c|c|}
\hline \multirow{3}{*}{$\begin{array}{ll}\text { Patient } & \text { Perception } \\
\text { of } & \text { Assurance } \\
\text { (Assurance) }\end{array}$} & \multicolumn{4}{|c|}{ Service Utilization } & \multicolumn{2}{|c|}{ TOTAL } & \multirow[t]{3}{*}{ Pvalue } & \multirow{2}{*}{$\begin{array}{l}\text { OR (95\%) } \\
\mathrm{Cl})\end{array}$} \\
\hline & \multicolumn{2}{|r|}{ Visit } & \multicolumn{2}{|c|}{ Don't Visit } & \multirow[b]{2}{*}{$\mathrm{N}$} & \multirow[b]{2}{*}{$\%$} & & \\
\hline & $\mathrm{N}$ & $\%$ & $\mathrm{~N}$ & $\%$ & & & & \\
\hline Good & 34 & $47,9 \%$ & 37 & $52,1 \%$ & 71 & $100 \%$ & 0,023 & 0,305 \\
\hline Less & 7 & $21,9 \%$ & 25 & $78,1 \%$ & 32 & $\begin{array}{l}100 \\
\%\end{array}$ & & $-0,117$ \\
\hline Total & 41 & $39,8 \%$ & 62 & $60,2 \%$ & 103 & $100 \%$ & & 0,795 \\
\hline
\end{tabular}


TABLE 6: Analysis of the Relationship between Patient Reliability ( Reliability ) and Service Utilization

\begin{tabular}{|c|c|c|c|c|c|c|c|c|}
\hline \multirow{3}{*}{$\begin{array}{l}\text { Patient Perception } \\
\text { of Reliability ( Reli- } \\
\text { ability ) }\end{array}$} & \multicolumn{4}{|c|}{ Service Utilization } & \multicolumn{2}{|c|}{ TOTAL } & \multirow[t]{3}{*}{$P$ value } & \multirow{2}{*}{$\begin{array}{l}\text { OR ( } 95 \% \\
\mathrm{Cl})\end{array}$} \\
\hline & & Visit & & on't Visit & & & & \\
\hline & $N$ & $\%$ & $\mathrm{~N}$ & $\%$ & $\mathrm{~N}$ & $\%$ & & \\
\hline Good & 34 & $85,0 \%$ & 6 & $15,0 \%$ & 40 & $100 \%$ & 0,000 & 0.022 \\
\hline Less & 7 & $11,1 \%$ & 56 & $88,9 \%$ & 63 & $100 \%$ & & $-0,007$ \\
\hline Total & 41 & $39,8 \%$ & 62 & $60,2 \%$ & 103 & $100 \%$ & & 0,071 \\
\hline
\end{tabular}

clinical aspects, efficiency and effectiveness and customer safety. Therefore, the quality of services offered is important in health services. However, quality must come from the consumer's perspective because service quality is a service received by consumers of the service.

From the results of this study, it was found that there were 62 people $(60.2 \%)$ of outpatient services on the quality of outpatient services at the Port Medical Center Hospital (60.2\%) and outpatients who were still interested in using the service as many as 41 people with a percentage of $39.8 \%$.

Tangibel (Direct Evidence) of service according to Parasuraman [6] is in the form of the appearance of physical facilities, equipment, and various communication materials. The appearance, facilities, and physical infrastructure of the company as well as the condition of the surrounding environment are tangible evidence of the services provided by the service provider.

Based on the research in the table, it is known that as many as 50 people (89.3\%) respondents/patients who have a poor tangible perception (physical evidence) who are not interested in using outpatient services from a total of 56 people and 6 people $(10.7 \%)$ are still interested in returning to take advantage of outpatient services.

From the results of the Chi-square statistical test, it was obtained that $\mathrm{P}$ value $=$ 0.000 (P-value <0.05) concluded that Ho was rejected and Ha was accepted, which means that there is a significant relationship between patient perceptions of Tangibel (Physical Evidence) and Outpatient Service Utilization. The value of OR $=0.041$ means that respondents who stated that the service tangibility was not good had a 1.603 times greater chance of not visiting again using outpatient services.

Based on the description of the research results and the theory of physical evidence (tangible) of services above, the researchers conclude that tangibel (direct evidence) is one indicator that greatly influences how the form of service quality works to meet customer (patient) satisfaction, and Tangible is very influential on interest in repeat visits in utilizing outpatient services. This shows that the tangible quality in the Outpatient 
Hospital Port Medical Center is still far from what is expected by consumers/patients, so it is necessary to improve the quality of services for patients. This improvement can be done including increasing patient comfort by redesigning the layout of the practice room and waiting room to make it more comfortable, clean and tidy as well as changing comfortable chairs for patients, facilitating the patient calling system related to patient sequence lists, equipping public facilities such as Wifi, television, prayer room and clean and comfortable toilet.

Empathy (attention/caring) is the attention that is carried out personally or individually to customers by placing themselves in the customer's situation, including ease of making relationships, good communication and understanding customer needs. Empathy is individualized attention to customers.

The results showed the results showed 7 people $(17.9 \%)$ rated the empathy of the service as not good and were still interested in visiting again by utilizing outpatient services, but 32 people (82.1\%) had a bad perception who were not interested in revisiting the service. So based on the Chi-square statistical test, the results of $P$ value $=0.001(\mathrm{P}<0.05)$ concluded that $\mathrm{Ho}$ was rejected and $\mathrm{Ha}$ was accepted, which means that there is a significant perception relationship about empathy (attention) with the use of outpatient services. The value of $\mathrm{OR}=0.374$ means that respondents who have a bad perception have a big risk opportunity 0.373 times not visiting again using outpatient services.

Reliability is the ability to provide services as promised, reliable, accurate, consistent, and in line with expectations. Conforming to customer expectations means timely performance, error-free service, sympathetic attitude, and high accuracy.

Based on the results of the study in table 3.3, it is known that the results showed 56 people $(88.9 \%)$ rated the reliability of the service as not good and were not interested in using the service, but 7 people (11.1\%) had a bad perception that they were still willing to reuse the service. Based on the Chi-square statistical test, the results obtained $P$ value $=0.000(\mathrm{P}<0.05)$, the conclusion is $\mathrm{Ho}$ is rejected and $\mathrm{Ha}$ is accepted, which means that there is a significant relationship between patient perceptions of reliability and the use of outpatient services. The value of $\mathrm{OR}=0.022$ means that respondents who have a bad perception have a great risk of 0.022 times not visiting to use the service again.

Responsiveness (responsiveness) is the responsiveness of employees in providing the services needed and can be completed quickly. The speed of service provided is the responsiveness of the officer in providing the required service. This responsive attitude is a result of reason and thought shown to the customer. 
The results showed that 3 people (5.1\%) rated the responsiveness of the service as not good but still wanted to visit again using the service and 56 people (94.9\%) had a bad perception that they were not interested in using the service again. So based on the Chi-square statistical test, the results obtained $P$ value $=0.000(P<0.05)$, the conclusion is $\mathrm{Ho}$ is rejected and $\mathrm{Ha}$ is accepted, which means that there is a significant relationship between patient perceptions of responsiveness and the use of outpatient services. The value of $\mathrm{OR}=0.008$ means that respondents who have a bad perception have a great risk of 0.008 times not visiting to use the service again

Time is Money applies to assessing the quality of health services from the economic aspect of its users. Where health services that are responsive to the needs of their customers are mostly determined by the attitude of the front line staff, because they are directly related to service users and their families. Port Medical Center improves the quality of its Responsiveness so that patient satisfaction is achieved by increasing the number of visits.

Assurance (guarantee) includes knowledge, ability, courtesy and trustworthiness of employees, free from danger, risk and doubt. Guarantee is a protective effort that is presented to the community for its citizens against risks which if that risk occurs will cause disruption in the normal structure of life.

The results showed that there were 7 people $(21.9 \%)$ who had a bad perception but were interested in visiting again, while there were 25 people $(78.1 \%)$ who assessed that the Assurance (Guarantee) service was not good and were not interested in using outpatient services. So based on the Chi-square statistical test, the results of $\mathrm{P}$ value $=$ $0.023(\mathrm{P}<0.05)$ concluded that Ho was rejected and Ha was accepted, which means that there is a significant relationship between patient perceptions of Assurance and the use of outpatient services. The value of $\mathrm{OR}=0.305$ means that respondents who have a bad perception have a large risk of 0.509 times not visiting to use the service again.

\section{Funding}

No Funding for this study.

\section{Conflict of Interest}

We declare no conflict of interest. 


\section{References}

[1] Herlambang S. Hospital health service management. Yogyakarta: Gosyen Publishing; 2016.

[2] Ministry of Health of Republic of Indonesia. Number of hospitals in Indonesia. Ministry of Health of Republic of Indonesia; 2019. Available from: https://pusdatin.kemkes.go.id/resources/download/pusdatin/profil-kesehatanindonesia/Profil-Kesehatan-indonesia-2019.pdf

[3] McDougall GHG, Levesque T. Customer satisfaction with services: Putting perceived value into the equation. Journal of Services Marketing

[4] Parasuraman A, Zeithaml VA, Berry LL. Reassessment of expectations as a comparison standard in measuring service quality: Implications for further research. Journal of marketing. 1994;58:111-124.

[5] Arifin M, Sumitri S, Lestari Y. Patients satisfaction about nursing care. Jurnal IImu Kesehatan. 2013;5:96583.

[6] Parasuraman A, ZeithamI VA, Berry L. Servqual: A multiple-item scale for measuring consumer perceptions of service quality. 1988;64:12-40. 